\title{
Occurrence of calcium oxalate in relation to the activity of fungi in forest litter and humus
}

\author{
VEIKKO HINTIKKA, KARI KORHONEN and \\ OSSI NÄYKKI
}

\begin{abstract}
HINTIKKA, V., KORHONEN, K. \& NÄYKKI, O. 1979: Occurrence of calcium oxalate in relation to the activity of fungi in forest litter and humus. - Karstenia 19: $58-64$.

Substantial quantities of calcium oxalate annually reach the ground with the forest litter, primarily in the form of calcium oxalate monohydrate. More calcium oxalate is produced by soil fungi, in the form of both monohydrate and dihydrate. The quantities of calcium bound in calcium oxalate are notably high in litter as compared with the amounts of exchangeable calcium. In the case of humus, on the other hand, the corresponding proportion is usually small because oxalate breaks down rather rapidly in the soil. For some reason, however, it seems that calcium oxalate accumulates to a much greater extent in white rot than in brown rot. Despite the fact that a large number of basidiomycetous fungi are capable of using oxalate, they seem to be of only minor importance in the break-down of calcium oxalate.
\end{abstract}

Veikko Hintikka, Institute of General botany, University of Helsinki, Viikki, SF00710 Helsinki 71 , Finland.

Kari Korhonen, Department of Forest Protection, Finnish Forest Research Institute, Unioninkatu $40 \mathrm{~A}, \mathrm{SF}$-00170 Helsinki 17, Finland.

Ossi Näykki, Institute of Geology and Mineralogy, University of Helsinki, Snellmaninkatu 5, SF-00170 Helsinki 17, Finland.

Oxalate is a common fungal metabolite, which is often produced in quantities both in nature and in aseptic cultures (Cochrane 1958, Hintikka 1970, Hodgkinson 1977, Graustein et al. 1977). It also occurs very frequently in higher plants (Hegnauer 1962-1966, Hodgkinson 1977) and usually enters the soil litter in the form of calcium oxalate. According to determinations made by Chandler (1937), the litter from certain American tree species contains $0.0-16.1$ me. oxalate $/ 10 \mathrm{~g}$ dry matter $(0-7.2 \%)$. Hintikka's (1970) determinations on litter from Finnish forest trees gave oxalate contents of between 30.8 and 88.0 me. $/ 10 \mathrm{~g}(0.3-0.9 \%)$. It seems evident that oxalate affects both the soil biology and chemistry, e.g. by preventing the leaching of calcium from the rooting zone and by complexation of aluminium (Graustein et al. 1977).

Calcium oxalate crystallizes in plants in two forms of hydrate: a monoclinic monohydrate, or whewellite, and a tetragonal dihydrate, or weddellite (Honegger 1952, Philipsborn 1952, Arnott et al. 1965, Sterling 1965). The latter hydrate is metastabile at physiological temperatures, tending to change gradually into the monohydrate form (Frey 1925). Many plants also contain soluble oxalate. Usually, however, there seems to be a distinct positive correlation between the calcium and oxalate contents of plants (Lötsch \& Kinzel 1971, Zindler-Frank 1975).

The quantities of oxalate annually reaching the soil with the litter and produced through the metabolism of various organisms must be relatively large. It is known, on the other hand, that oxalate disappears from the soil rather rapidly (Waksman 1938, Viro 1962). The organisms which consume most of the oxalate reaching the soil are probably bacteria. Bassalik (1913) found that Bacillus extorquens (Pseudomonas e.; Janota 1957), which he had isolated from the excrement of earthworms, decomposed the calcium oxalate crystals in the course of a few weeks. Several other oxalate-decomposing bacteria have also been isolated from various sources (reviewed by Hodgkinson 1977). At least some of these bacteria seem to be capable of utilizing calcium oxalate, the solubility of which in water is some $6-7$ 
$\mathrm{mg} / \mathrm{l}$, as their sole carbon source (Bassalik 1913, Bhat \& Parker 1948). The solubility of calcium oxalate, however, increases in the presence of certain ions, for example, magnesium and citrate (Elliot \& Eusebio 1965).

In addition, many fungi are able to decompose oxalate (Emiliani \& Riera 1968). Among the Basidiomycetes, white-rot fungi are usually capable of using the oxalate that is formed as a by-product of their metabolism. This is not possible in the case of most brown-rot fungi (Shimazono 1955). On the other hand, white-rot fungi, too, precipitate oxalate in the form of calcium oxalate if there is sufficient calcium available (Takao 1965).

The behaviour of oxalate in the soil has not been assessed in detail although this problem might be of interest, for example, bearing in mind the calcium cycle and soil acidity. It can be assumed that calcium oxalate represents a readily mobilizable calcium reserve in the soil which, however, cannot be detected in the determination of exchangeable calcium. The present paper describes some preliminary experiments which were performed primarily in order to assess the importance of the role played by fungi in the oxalate balance of soils.

\section{Crystalline calcium oxalate in pure cultures}

A preliminary investigation was carried out on the capacity of some litter-decomposing fungi (Collybia butyracea (Bull. ex Fr.) Quél., Marasmius androsaceus (L. ex Fr.) Fr., M. urens Fr., Micromphale perforans (Hofm. ex Fr.) Sing., and Mycena galopoda (Pers. ex Fr.) Kummer) to produce crystalline calcium oxalate in pure culture. Strains of these fungi were grown on different agar substrates, on filter paper and on sterilized litter. The crystals produced were examined using both a light and a polarization microscope. The mono- and the dihydrate forms were distinguished from each other on the basis of the shape of the crystals and their interference colours, as well as by determining their refraction coefficients (Frey-Wyssling 1935).

The strains which were used in the experiments produced calcium oxalate crystals that were both unattached on the substrate and attached to the hyphae. The largest numbers of crystals were found in the oldest parts of the mycelia. The crystals occurring on the substrate were representative of both the mono- and dihydrate forms, the only exception being Mycena galopoda which produced only the dihydrate form. In each species studied, the crystals which were attached to the hyphae were of only one type of hydrate: the Marasmius species and
Micromphale perforans produced the monohydrate form, whereas Collybia butyracea and Mycena galopoda produced the dihydrate form.

The calcium oxalate monohydrate present in the pure cultures usually occurred in the form of flat, prismatic crystals and of aggregates built up of such crystals (Fig. 1). The shape and thickness of the crystals showed rather large variation, and most of them seemed to be twins. The pseudorhomboedric single crystals frequently found in vascular plants (Fig. 6) were rare in pure cultures. When the monohydrate form was present on the hyphae, it frequently formed an almost uniform sheath around the hyphae, consisting of small roundish and flat crystals and their aggregates (Fig. 2).

The calcium oxalate dihydrate mostly occurred in the pure cultures as single crystals, the shape of which varied from that of bipyramids to pin-shaped, depending on the length of the prism (Fig. 3) (Hamada 1939). Aggregates were also found rather often, and sometimes even spherulites. Having crystallized on the hyphae, the dihydrate occurring on Collybia butyracea (long, pin-shaped crystals; Fig. 4) was quite different from that occurring on Mycena galopus (small prisms or bipyramides; Fig. 5).

The form in which the hydrate occurs is dependent on many physical and chemical factors of which the $\mathrm{pH}$ is one of the most important: the monohydrate form is usually produced at low $\mathrm{pH}$ values, and dihydrate in neutral and basic conditions (Pfeiffer 1925, Kohlschütter \& Marti 1930). It also seems that each species of fungus tends to form hyphal crystals of a similar type even when growing on different substrates. It has not been established so far, however, to what extent this phenomenon can be used in identifying the hyphae of different species.

\section{Calcium oxalate crystals in litter and in soil}

In order to get an idea of the occurrence of calcium oxalate crystals in litter and in forest soil, samples were examined which had been collected from litter and humus formed by the commonest Finnish forest plants. The samples were bleached using sodium hypochlorite or chloral hydrate, and microscopic slides were made from both crushed and cut material. The crystals were examined under both a light and a polarization microscope. Crystals were isolated in their pure form from crushed leaves of blueberry and birch by the flotation method using a mixture of bromoform and alcohol. The crystals which have been isolated from the leaves of blueberry were also identified using $\mathrm{x}$-ray diffraction analysis. 

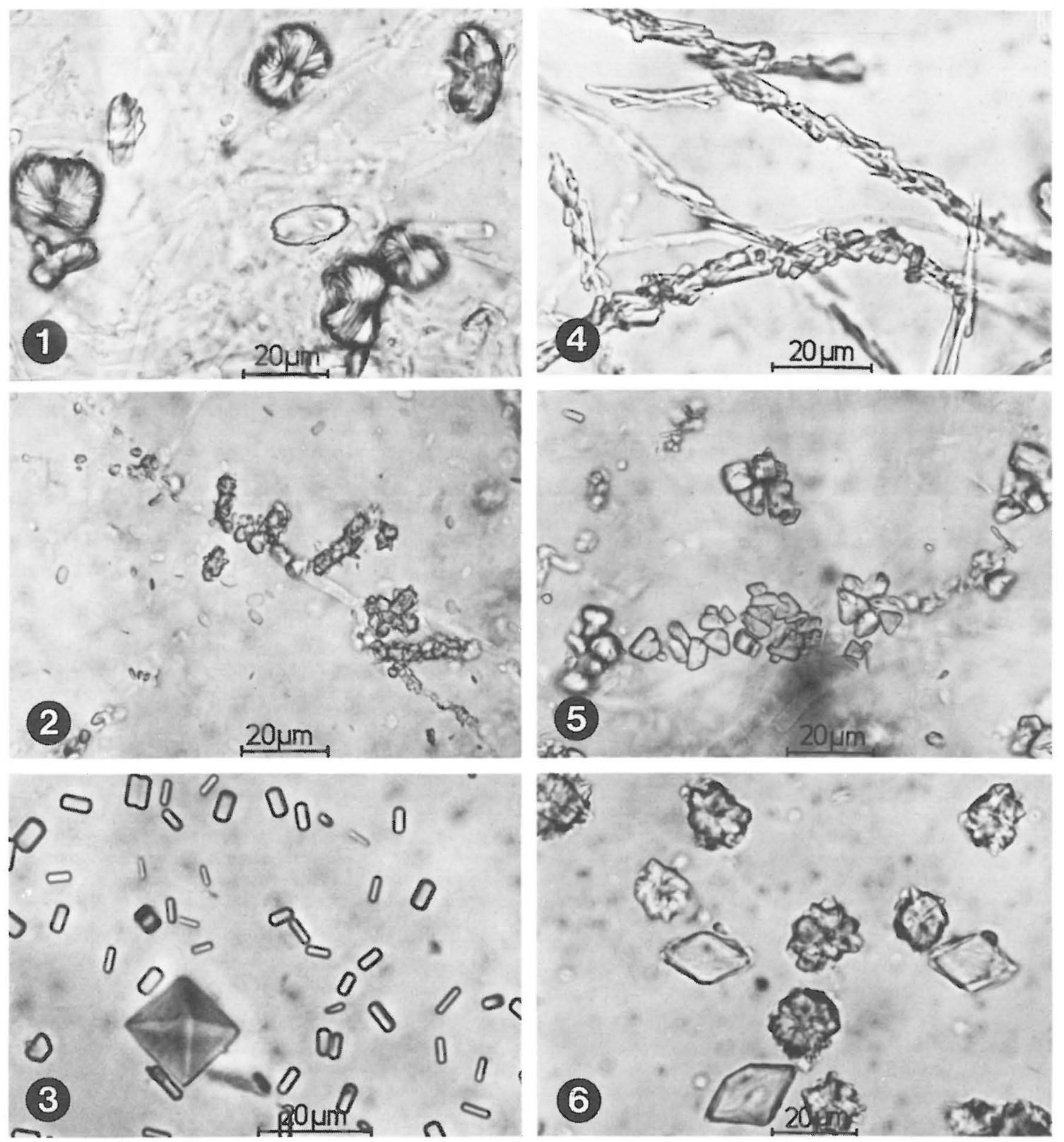

Figs. 1-6. - 1: Aggregates of calcium oxalate monohydrate in the culture medium of Marasmius urens. - 2: Sheaths formed of monohydrate crystals on the hyphae of $M$. androsaceus. - 3: Calcium oxalate dihydrate: small pins and a bipyramid in the culture medium of Micromphale perforans. - 4: Dihydrate crystals attached to the hyphae of Collybia butyracea. - 5: Dihydrate crystals on the hyphae of Mycena galopoda. - 6: Single crystals and aggregates of calcium oxalate monohydrate isolated from birch leaves. 
Calcium oxalate crystals occur frequently, often even abundantly, in many of the most important types of litter, especially in leaves from hardwoods (Table 1). Only the monohydrate form was found in the litter samples examined, mostly in the form of aggregates and single crystals with a large diameter (Fig. 6), but also styloid crystals (Pinus sylvestris L., Convallaria majalis L.) and raphide bunches (Convallaria majalis, Epilobium angustifolium L.) were observed. According to Frey (1925), dihydrate occurs first and foremost in 'Wassergeweben' of higher plants, whereas monohydrate is found in 'Bildungsgeweben, mechanisches System, Assimilationsgewebe, Leitungssystem'. In addition to the types of litter presented in Table 1, calcium oxalate crystals were also found in the leaves of, for example, the following plant species: Pinus sylvestris, Alnus glutinosa (L.) Gaertner, Fragaria vesca L., Oxalis acetosella L., Arctostaphylos uva-ursi (L.) Sprengel, Vaccinium vitis-idaea L., Empetrum nigrum L. and
Linnaea borealis L. On the other hand, calcium oxalate crystals were absent from plants representing the families Lycopodiaceae, Polypodiaceae (s. lat.), Poaceae, Cyperaceae, Apiaceae, etc., and from the species Maianthemum bifolium (L.) F.W. Schmidt, Trientalis europaea L. and Orthilia secunda (L.) House (cf. Hegnauer 1962-1966).

The calcium oxalate crystals disintegrate during the decomposition of the litter. They seem to be better preserved in white rot than in brown rot. Thus, for example, the leaf-blade tissue of aspen leaves usually disintegrates in white rot humus before the calcium oxalate crystals disappear from the nerves of the leaves. Frequently, too, the nerves break down, releasing any calcium oxalate crystals present. In the case of brown rot, on the other hand, it seems that the crystals disappear from the leaf nerves before disintegration of the leaf-blade tissue has advanced to any considerable extent (Fig. 7).

In decaying litter, new calcium oxalate crystals are

Table 1. Exchangeable calcium in litter and humus samples as determined by ammonium acetate extraction and amounts of $\mathrm{HCl}$-soluble calcium and oxalate determined after extraction. Presence of calcium oxalate crystals in samples is indicated.

\begin{tabular}{cccl} 
& \multicolumn{2}{c}{ me $/ 100 \mathrm{~g}$ dry matter } & \\
exchangeable & Oxalate & Presence \\
& in $\mathrm{HCl}$ & in $\mathrm{HCl}$ & of Ca-oxalate \\
& extract & extract & crystals in \\
& & & samples
\end{tabular}

Litter samples

Trees

Salix caprea L. (leaves)

Populus tremula L., (leaves)

69.0

33.2

29.8

26.4

$B$. pubescens Ehrh. (leaves)

Alnus incana (L.) Moench (leaves)

28.8 .

Herbs and dwarf shrubs:

Convallaria majalis L. (shoots)

Rubus idaeus L. (leaves)

29.7

$R$. saxatilis L. (leaves)

Solidago virgaurea L. (shoots)

Vaccininium myrtillus L. (leaves)

Epilobium angustifolium L. (shoots)

Calluna vulgaris (L.) Hull (shoots)

Eguisetum sylvaticum L. (shoots)

Dryopteris carthusiana (Vill.) H.P. Fuchs

Pteridium aquilinum (L.) Kuhn

Calamagrostis epigejos (L.) Roth (shoots)

C. phragmitoides Hartman (shoots)

Melampyrum pratense L. (shoots)

Humus samples (brown rot)

collected from Ruotsinkylä Experimental Forest, Tuusula

OMT birch stand

50.3

OMT mixed stand (spruce, birch)

37.3

OMT mixed stand (birch, spruce)

$\begin{array}{rr}36.4 & 27.2 \\ 40.7 & 25.6 \\ 18.1 & 13.5 \\ 30.5 & 20.7 \\ 21.7 & 19.0 \\ 11.4 & 7.3\end{array}$

+
+
+
+
+
+

25.2

15.8

22.2

19.6

11.2

8.9

3.7

9.8

9.5

2.6

0.4

0.5

7.8

14.4

10.5

10.4

8.1

6.6

2.8

1.9

-

$-$

-

15.3

10.6

18.8
8.3

2.3

1.4
$+$

$+$

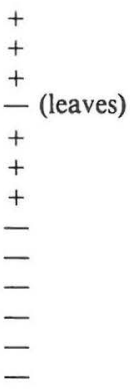




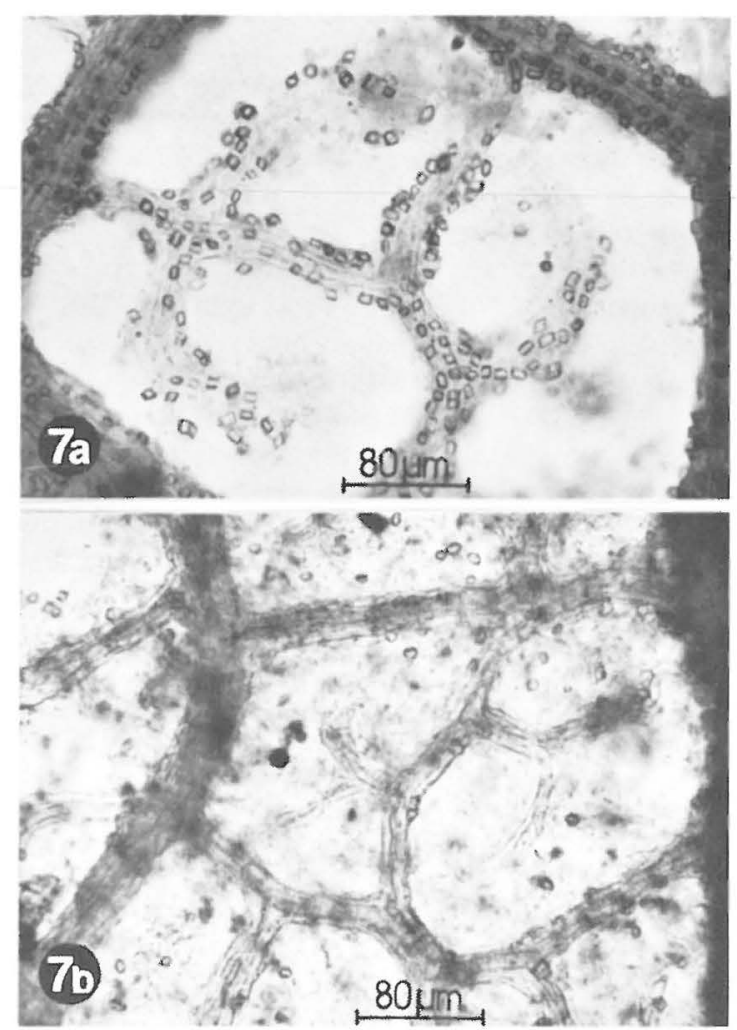

Fig. 7. A part of a leaf of Populus tremula being decayed in white rot humus (a), and in brown rot humus (b). In white rot humus the calcium oxalate crystals are still present although the leaf blade tissue has already disappeared. In brown rot humus the crystals have dissolved before leaf blade tissue has completely decayed.

also formed, probably primarily as a result of fungal metabolism. These are small detached crystals or aggregates of different shapes, usually more or less roundish, and their crystalline form is frequently not clearly discernible. As in the case of the pure cultures, the crystal aggregates often form a sheath around the hyphae, this being particularly conspicuous in the case of white rot. The calcium oxalate crystals produced by the fungi concerned are both monohydrate and dihydrate.

According to the results obtained from experiments performed in the laboratory, litterdecomposing fungi do not break down calcium oxalate crystals. In contrast, they themselves produce large amounts of such crystals. The situation may of course be different if there is a deficiency of calcium, at least in the case of white-rot fungi, which are capable of utilizing calcium oxalate (Takao 1965).
The presence of bacteria which break down calcium oxalate in the humus of a mixed forest of the Myrtillus site type was demonstrated by means of the enrichment methods of Müller (1950) and Bhat \& Parker (1948).

\section{Calcium and oxalate determinations}

As calcium oxalate seems to represent a readily discernible and mobilizable calcium reserve in the soil which, however, remains undetected in exchangeable calcium determinations, a number of orientative determinations were carried out in order to compare the quantity of exchangeable calcium and that occurring in the form of oxalate in litter and humus. The exchangeable calcium was determined using the ammonium-acetate method, as follows:

4-6 $\mathrm{g}$ of litter which had been stored in a freezer was weighed for analysis. In the case of humus samples, about $20 \mathrm{~g}$ of material containing the smallest possible amounts of mineral soil particles was used. About $50 \mathrm{ml}$ of ammonium acetate solution ( $\mathrm{pH} 4.65,1 \mathrm{~N}$ in respect to the acetate) was added to the sample, and the mixture then homogenized with cooling in a Sorvall Omni-Mixer. It was then washed into a beaker, and left to stand overnight. The sample was extracted the following day using $6 \times 25 \mathrm{ml}$ of ammonium acetate solution in a Büchner funnel $(\varnothing 5.5 \mathrm{~cm}$, Whatman 42 paper) over a period of at least two hours. A centrifuge was used in the extraction of some samples which were difficult to filter, and the supernatant then filtered. The ammonium acetate extract was dried by evaporation (Jackson 1962: 86), and the amount of calcium determined on an atomic absorption spectrophotometer.

The precipitate that remained in the Büchner funnel was extracted with $1 \mathrm{~N}$ hydrochloric acid (heated and left to stand overnight), and the amount of oxalate and calcium in the extract determined.

Oxalate was determined using Kuhlen's (1966) variation of the Baker method in which oxalate is dissolved in hydrochloric acid, precipitated with calcium, the precipitate dissolved in hot $4 \mathrm{~N}$ sulphuric acid, and titrated with potassium permanganate.

Particularly in the case of humus samples, however, the calcium oxalate is not always precipitated in a pure form. Instead, an impure brownish precipitate is formed. The impurities do not dissolve when washed with $5 \%$ acetic acid. They are slowly oxidized by potassium permanganate and make the end point of the titration unclear. In cases where such a brown precipitate was formed $1 \mathrm{ml}$ of $30 \%$ hydrogen peroxide was added to the washed precipitate and evaporated to dryness in a boiling water bath. Evaporation was continued for a few hours at a temperature of $60^{\circ} \mathrm{C}$. The precipitate was washed once with $5 \%$ acetic acid, dissolved in hot $4 \mathrm{~N}$ sulphuric acid and titrated with potassium permanganate. The hydrogen peroxide treatment did not seem to affect the calcium oxalate and the end point of the titration could be determined more accurately.

The results obtained in the study (Table 1, Fig. 8) indicate that a considerable amount of the calcium occurring in several important types of litter is bound 


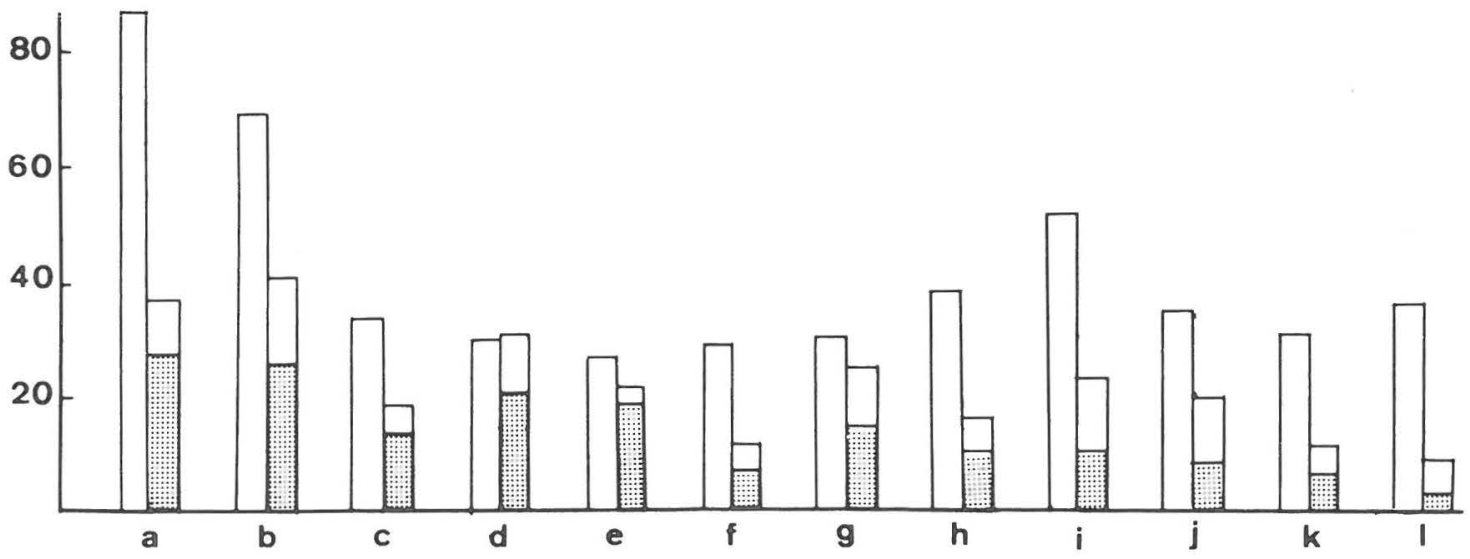

Fig. 8. Comparison between the exchangeable calcium in some litter samples as determined from ammonium acetate extraction (left column), and the amount of $\mathrm{HCl}$-soluble calcium remaining in the sample after ammonium acetate extraction (right column). The shaded part of the right column shows the amount of calcium remaining in the sample in the form of calcium oxalate, under the assumption that all the sparingly soluble oxalate is bound as calcium oxalate. Vertical axis: me. Ca/ 100 g dry matter. a: Salix caprea, b and c: Populus tremula, d: Betula sp., e: Betula pubescens, f: Alnus incana, g: Convallaria majalis, h: Rubus idaeus, i: Rubus saxatilis, j: Solidago virgaurea, k: Vaccinium myrtillus, l: Epilobium angustifolium.

as calcium oxalate. This means that it is not measured in determinations of exchangeable calcium. On the basis of some determinations made on humus, on the other hand, the importance of calcium oxalate occurring in brown rot is negligible.

When the results are examined, it should be kept in mind that a part of the calcium oxalate present in the samples may be dissolved by the solvent used in the ammonium acetate extraction preceding oxalate determination. Thus, the results may give a slightly erroneuous idea of the calcium oxalate content of the samples, and likewise, comparison of these values with those obtained in previous studies might be somewhat misleading. Thus, for example, according to the figures presented by Chandler (1937), litter from American forest trees appear to contain more oxalate than that recorded in the present study. Furthermore, a larger proportion of the total amount of calcium seems to be bound in calcium oxalate in American than in Finnish forest litter. Viro (1962), too, gives higher oxalate contents for litter than those recorded in the present study. Except in the case of Vaccinium myrtillus, on the other hand, the present values do not differ much from those recorded by Hintikka (1970).

According to determinations made on brown rot, the rather high oxalate content of litter seems to decrease rapidly with the advance of litter decomposition. This takes place despite the activity of fungi which may produce oxalate. Generally speaking, calcium oxalate seems to be of minor importance for the calcium balance in brown rot. In the case of white rot, on the other hand, the situation may be different. Determinations were not carried out on white rot, but on the basis of data obtained by Hintikka (1970), it can be calculated that white rot contains an average of $15.3 \mathrm{me} / 100 \mathrm{~g}$, and brown rot, $4.2 \mathrm{me} / 100 \mathrm{~g}$ of oxalate. If we assume that all of it is calcium oxalate, the quantity of calcium bound in oxalate corresponds, in the case of white rot, to some $40 \%$ of the exchangeable calcium as determined by means of the ammonium acetate method in the same study, and in the case of brown rot, to about $10 \%$ of the exchangeable calcium recorded.

Acknowledgements. This work has been carried out at the Department of Forest Biology (now: Department of Forest Protection), Finnish Forest Research Institute. Näykki has been responsible for the mineralogical identification of the crystals and related aspects, Hintikka and Korhonen for the mycological and chemical aspects.

\section{References}

Arnott, H.J., Pautard, F.G.E. \& Steinfink, H: 1965. Structure of calcium oxalate monohydrate. - Nature 208: 1197-1198.

Bassalik, K. 1913: Über die Verarbeitung der Oxalsäure durch Bacillus extorquens n. sp. - Jahrb. Wiss. Bot. 53: $255-302$.

Bhat, J.W. \& Parker, H.A. 1948: Studies on a new oxalatedecomposing bacterium, Vibrio oxalaticus. - J. Bacteriol. 55: 359-368.

Blackmore, M.A. \& Quayle, J.R. 1970: Microbial growth on oxalate by a route not involving glyoxylate carboligase. - Biochem. J. 118: 53-59.

Chandler, R.F. 1937: Certain relationships between the calcium and oxalate content of certain forest trees. - J. Agr. Research 55: 393-396. 
Cochrane, V.W. 1958: Physiology of fungi. -524 p. New York, London.

Elliot, J.S. \& Eusebio, E. 1965: Calcium oxalate solubility: The effect of inorganic salts, urea, creatinine, and organic acids. - Invest. Urol. 3: 72-76.

Emiliani, E. \& Riera, B. 1968: Enzymatic oxalate decarboxylation in Aspergillus niger. 2. Hydrogen peroxide formation and other characteristics of the oxalate decarboxylase. - Biochim. Biophys. Acta 167: 414-421.

Frey, A. 1925: Calciumoxalat-Monohydrat und Trihydrat in der Pflanze. - Vierteljahrsschrift der Naturforschenden Gesellschaft in Zürich 70: 1-65.

Frey-Wyssling, A. 1935: Die Stoffausscheidung der höheren Pflanzen. -378 p. Berlin.

Graustein, W.C., Cromack, K.Jr. \& Sollins, P. 1977: Calcium oxalate: Occurrence in soils and effect on nutrient and geochemical cycles. - Science 198: $1252-1254$.

Hamada, M. 1939: Studien üben die Mykorrhiza von Galeola septentrionalis Reichb.f. Ein neuer Fall der Mykorrhiza-Bildung durch intraradicale Rhizomorpha. - Japan. J. Bot. 10: 151-211.

Hegnauer, R. 1962-1966: Chemotaxonomie der Pflanzen I-IV. - Basel-Stuttgart.

Hintikka, V. 1970: Studies on white-rot humus formed by higher fungi in forest soils. - Comm. Inst. Forest. Fenn. 69(2): 1-68.

Hodgkinson, A. 1977: Oxalic acid in biology and medicine. - 325 p. London, New York, San Francisco.

Honegger, R. 1952: Das Polyhydrat des Kalzium-Oxalates. - Diss. Zürich. $44 \mathrm{p}$.

Jackson, M.L. 1962: Soil chemical analysis. 3rd printing. 498 p. Englewood Cliffs, N.J.

Janota, L. 1957: Further researches on Pseudomonas extorquens Bassalik. A microorganism utilizing oxalic acid. - Acta Soc. Botan. Polon. 26: 207-214.
Kohlshütter, V. \& Marti, J. 1930: Über Bildungsformen des Calciumoxalats. - Helv. Chim. Acta 13: 929-978.

Kuhlen, H. 1966: Vergleichende methodische Untersuchungen über die Bestimmung der Oxalsäure in Pflanzenmaterial. - Gartenbauwissenschaft 31: $101-113$.

Lötsch, B. \& Kinzel, H. 1971: Zum Calciumbedarf von Oxalatpflanzen. - Biochem. Physiol. Pflanzen 162: 209-219.

Müller, H. 1950: Oxalsäure als Kohlenstoffquelle für Mikroorganismen. - Arch. Mikrobiol. 15: 137-148.

Pfeiffer, H. 1925: Über die Wasserstoffionenkonzentration als determinationsfaktor physiologischer Gewebegeschehen in der sekundären Rinde der Pflanzen. New Phytol. 24: 65-98.

von Philipsborn, H. 1952: Über Calciumoxalat in Pflanzenzellen. - Protoplasma 41: 415-424.

Shimazono, H. 1955: Oxalic acid decarboxylase, a new enzyme from the mycelium of wood destroying fungi. - J. Biochem. 42: 321-340.

Sterling, C. 1965: Crystal structure analysis of weddellite, $\mathrm{CaC}_{2} \mathrm{O}_{4}(2+\mathrm{x}) \mathrm{H}_{2} \mathrm{O}$. - Acta Crystallographica 18: $917-921$.

Takao, S. 1965: Organic acid production by Basidiomycetes 1 . Screening of acid producing strains. - Appl. Microbiol. 13: 732-737.

Viro, P.J. 1962: Methods of chemical analysis for site evaluation. - International Union of Forest Research Organisations, 13th Congress, Vienna 1961: 21 - 3/9. 9 p.

Waksman, S.A. 1938: Humus. Origin, chemical composition and importance in nature. $-526 \mathrm{p}$. Baltimore.

Zindler-Frank, E. 1975: On the formation of the pattern of crystal idioblasts in Canavalia ensiformis DC.VII. Calcium and oxalate content of the leaves in dependence of calcium nutrition. - Z. Pflanzenphysiol. 77: 80-85. 